\section{EMBRYRIDDLE}

Aeronautical University

SCHOLARLY COMMONS
Journal of Aviation/Aerospace Education \& Research

Volume 18

Number 1 JAAER Fall 2008

Article 9

Fall 2008

\title{
The Perceived Need for Training and Potential Training Topics for Indiana Airport Board Members
}

R. Troy Allen

Follow this and additional works at: https://commons.erau.edu/jaaer

\section{Scholarly Commons Citation}

Allen, R. T. (2008). The Perceived Need for Training and Potential Training Topics for Indiana Airport Board Members. Journal of Aviation/Aerospace Education \& Research, 18(1). https://doi.org/10.15394/ jaaer.2008.1393

This Article is brought to you for free and open access by the Journals at Scholarly Commons. It has been accepted for inclusion in Journal of Aviation/Aerospace Education \& Research by an authorized administrator of Scholarly Commons. For more information, please contact commons@erau.edu. 


\title{
THE PERCEIVED NEED FOR TRAINING AND POTENTIAL TRAINING TOPICS FOR INDIANA AIRPORT BOARD MEMBERS
}

\author{
R. Troy Allen
}

\begin{abstract}
Individuals who serve as airport board members in the state of Indiana are not required by law to have any aviation experience or training. This study was completed to determine the perceived need for airport board member training in the state of Indiana and identify potential training topics.

Thirty Indiana public-use airport managers and thirty airport board members were surveyed. Twenty-one topic areas were rank ordered by mean value and two additional survey questions were asked to determine if airport board members and airport managers believed that training would be beneficial.

A Spearman Rank Order Correlation indicated that there is a strong correlation $\left(r_{s}=.9018\right)$ among the study participants when rank ordering potential training topics. An Analysis of Variance found that there is no statistically significant difference exist between the two groups when they were asked if training would be beneficial $F(1,2)=$ $1.59, p<.05$. Additionally, all of the suggested training topics were perceived as important and should be included if training were developed.
\end{abstract}

\section{INTRODUCTION}

According to the Federal Aviation Administration's National Plan of Integrated Airports Systems (NPIAS), as of July 2006, the United States had 19,847 airports. Of those airports, 707 are located in Indiana. Of the 707 airports, approximately 112 are defined by Indiana Administrative Code 105 (IAC 105) as "public-use." These public-use airports are available for any pilot to use for aircraft operations. The remaining 595 Indiana airports are defined by IAC 105 as private-use airports. To legally land an aircraft at a private-use airport, a pilot must receive permission from the owner. These 595 airports are outside of the confines of this study.

Of the 112 airports listed as public-use, another subset can be defined when considering their ownership. Of these 112 public-use airports, 71 are owned by the public and known as public-use airports. The remaining 41 airports in the system are privately owned and are not included in this study.

At each of these 71 public-use airports, there is an associated airport board. This airport board is in charge of governing the airport. This study will focus on the individuals who serve on an airport board at a public-use airport. These individuals are known as airport board members. Airport board members currently serve at each of these 71 publicly owned public-use airports. In order to serve on an airport board, these individuals must meet regulatory requirements set forth in Indiana Code 8-22-2 and 8-22-3.

"Many different education and training methods exist for airport personal" (Quilty, 2003, p.12); however, a review of the training offered to airport board members shows that this group of aviation professionals has virtually no training offered to them or required of them. Obviously, the importance of training is understood in the aviation industry, so why is there very little offered to airport board members? Is there no perceived need for airport board member training and thus the lack thereof? This study examines this issue to determine whether airport officials believe there is or is not a need for airport board member training and what subject matter would be most valuable if such training were created.

Understandably, the airport board members do not need to have the same level of knowledge of airport 
operations as airport managers. However, that they need at least a general understanding of the airport environment in order to be effective in their appointed positions makes sense. In addition, there may be other non-aviation related topics that would be beneficial to include if training were developed.

\section{Research Questions}

These questions are the basis for the subset of questions that were asked of the respondents and guided this research:

1. Is there a difference between airport managers and airport board members in regard to their level of agreement with the statement: I perceive there would be a monetary savings for the airport if an airport board member were to receive training?

2. Is there a difference between airport managers and airport board members in regard to their level of agreement with the statement: Airport board members would be more effective in their position if they completed training?

3. What topic areas for airport board member training do airport board members and airport managers consider most important to include in airport board member training?

4. Is there a relationship between the airport managers and airport board members in their rankings of training topics?

\section{LIMITATIONS}

This study was limited to Indiana airport board members, thereby possibly limiting the generalizability of the study.

The respondent may not have understood all of the topics that were listed in the survey instrument as possible training topics.

It is assumed that the airport managers accurately assessed the level of understanding that an airport board members has on various training topics.

It is assumed that the respondents answered the questionnaire honestly.

\section{REVIEW OF THE LITERATURE}

"Determining and analyzing the training needs is the starting point for all training efforts" (Quilty, 2003, p. 6). With that thought in mind, this study set out to determine what training was presently being offered to airport board members and if that training was meeting the airport board member's needs.

An extensive internet search was conducted to determine what training is presently available to Indiana airport board members. Two workshops were discovered. The American Association of Airport Executives (AAAE) and the Airport Council International (ACI) host the airport commissioner workshop, and the Aviation Association of Indiana (AAI) has a workshop known as the Airport Board Member Workshop.

The AAAE/ACI workshop is a two-day training session that is designed to be relevant to any airport board member located in the United States. This training is not specifically designed to meet the needs of Indiana airport board members but is designed to meet the basic needs of any airport board member in the United States.

Furthermore, the short nature of this training and its inability to be asynchronous limit the ability of this training to meet the all of the training needs of this unique group of individuals.

The Aviation Association of Indiana (AAI) offers workshops, along with many other services, to airport officials working in the state of Indiana. One of its chief functions is lobbying on behalf of airports before the state legislature. Additionally, this association holds meetings where a wide variety of aviation individuals can share ideas and experiences. AAI has three quarterly meetings and one annual conference each year.

The AAI offers a one-day workshop for new airport board members during their annual conference. The workshop has been specifically designed to educate Indiana airport board members. An airport manager and a Federal Aviation Administration (FAA) engineer moderate the workshop. The airport board members are given a handbook as a future reference document, and it serves as a curricular guide for the instructors during the course. The handbook for this course is broken into nine chapters. Chapters found in the handbook cover the following areas:

1. Introduction to Aviation and Airports

2. Agency Roles

3. Airport Funding: What Are the Sources

4. Glossary

5. Indiana Code and Regulations

6. Economic Impact

7. AAI: What Is It

8. Membership Directory

9. Accident Report

The chapters within this handbook are in narrative form. The latest printing of the document occurred in October 2001.

This training serves a needed purpose in training the airport board members. However, airport board members who were contacted as a part of this study stated that they 
would not be reimbursed if they elected to attend this training and they would have to take a vacation day from their full time job in order to attend.

Contact was also made with an airport engineer at the Federal Aviation Administration (FAA) Great Lakes Regional Office. According to the airport engineer, the FAA does not offer any training for airport board members. Furthermore, he stated that there are no FAA Advisory Circulars (AC) that have been designed as source documents for the airport board members to reference. These AC's are developed to be source documents to explain proper procedures in the aviation industry and are used heavily by other aviation professionals.

\section{SURVEY}

\section{Instrument}

This research did not locate an adequate survey instrument for this study. However, several studies (Peters, 2005; Schaffer, 2001) were located and their survey instruments were used as basic models for the development of a survey instrument for this study.

Once the survey instrument (appendix A) was developed, the study set out to determine the validity of the survey instrument. According to Fraenkel and Wallen (2006) validity is "the degree to which correct inferences can be made based on results from an instrument" (p. 151). They go on to state that validity can come in several forms including construct related, criterion related, and content related.

In order to determine if the survey instrument had content-related validity, the study invoked the aid of members of the Indiana State University, Aerospace Department Advisory Council to review the survey instrument. This method in which to assure content validity is known as "validity by consultant." This group is comprised of aviation consultants, airline pilots, airport managers, and government officials working in the field of aviation. All of the individuals hold at least a bachelors degree and have years of experience in the field of aviation. They are considered experts in the field of aviation.

The individual members suggested ways in which to clarify the questions and suggested specific training topics to be included in the survey instrument. The suggestions and comments that were made by the group were integrated into the survey instrument.

Since an untested survey instrument was constructed, additional review was sought. Therefore, the survey instrument was presented to the Aviation Association of Indiana (AAI) Airport Board Member Committee for review. This committee is comprised of airport board members from around the state of Indiana. These committee members are all active airport board members serving at airports throughout Indiana. They serve at primary, commercial service, reliever, and general aviation airports. This diversity makes them an ideal group of experts to review the survey instrument for content validity. The feedback given by this group added much clarity to the survey instrument. The comments that came from this review suggested some additional training topics. The amendments suggested by the AAI Airport Board Member Committee were incorporated into the survey instrument.

Methodology

A telephone survey was selected as the most appropriate means to collect data for this study. According to Salant and Dillman (1994) this method of survey offers many advantages compared to other methods of data collection. Those advantages include rapid collection of data and greater interview control.

The sample selected from both populations was a simple random sample with replacement. This method assured that each subject in the population had an equal probability of being selected. Additionally, utilizing sample by replacement assured that no relationship existed between the selected subjects. This random sample was obtained by using an online research randomizer. The randomizer was able to generate two sets of a random number for the airport board member population and airport manager population. This randomizer allowed for the researcher to input a population number and then request a specific sample size be generated. The researcher obtained a $100 \%$ response rate by using this form of data collection.

\section{SURVEY POPULATION AND SAMPLE SIZE}

\section{Airport Board Members}

In order to determine the exact number of airport board members in the state of Indiana, data recorded and updated by the Indiana Department of Transportation (INDOT), Office of Aviation was referenced. This office produces a document titled Directory of Indiana Airports that list contact information for all of the airport managers and airport board members in Indiana. In addition to listing the public-use airports, the document also contains the names and telephone numbers for all of the airport board members and airport managers. This document indicates that the state of Indiana has 287 airport board members.

Considering the population size, a sample size of 30 respondents was selected as an acceptable number to represent the population. This sample size would also be adequate to fill the analysis of variance (ANOVA) cell size requirement of 10 to 15 subjects per cell. Without this minimum cell size, accurate inference cannot be made back to the population (Peters, 2005). 


\section{Airport Managers}

At each of the 71 publicly owned airports in the State of Indiana, there is an airport manager. These managers have a variety of educational backgrounds. Additionally, their level of experience in aviation is also diverse. The only requirement that they were required to meet in order to be a respondent in the study was to be presently serving as an airport manager at a publicly owned airport in the state of Indiana. This population consisted of 71 Indiana public-use airport managers.

With an associated sample size of 30 airport board members, it was decided to survey an equal number of airport managers. Therefore, it was determined that $\mathbf{3 0}$ airport managers would be surveyed.

\section{Reliability of the Survey Instrument}

Reliability is the ability of a testing instrument to obtain the same results when it is administered multiple times to the subjects. This survey instrument was only administered once to the subjects. Therefore, the ability to see that the same results were obtained through multiple testing was not possible. In order to obtain reliability Cronbach Alpha was utilized. It has been stated, "For research purposes, a useful rule of thumb is that reliability should be at least .70" (Fraenkel \& Wallen, 2006, p. 161). A high level of survey reliability was established using Cronbach's Alpha test for reliability $\left(r_{s}=.922\right)$. Therefore, internal rater reliability was tested and confirmed for the survey instrument.

\section{Research Question One}

\section{RESULTS}

Is there a difference between airport managers and airport board members in regard to their level of agreement with the statement: "I perceive there would be a monetary savings for the airport if an airport board member were to receive training?"

Using the data collected on this question, the researcher used SPSS to perform an analysis of variance (ANOVA) to determine if statistical significance exists between airport managers and airport board members and their agreement with this statement. Table 1 shows that statistical significance was found, $F(1,2)=5.97, p=<.05$. This indicated that the two groups do not agree with the assertion that there would be a monetary savings if training were completed. With that in mind, it is important to go beyond reviewing the ANOVA by consulting other statistics to better define the difference. Therefore, the mean values were used to better interpret the results of this question.

Airport managers perceived a greater cost savings with a mean of $\quad(M=4.13, S D=.819)$ than the airport board members who had a mean of only $(M=3.56, S D=$
.971). Although the ANOVA has shown there is statistical significance at the .05 level, the practical significance is more important when considering the amount of disagreement between the two groups. It can be seen that when comparing the mean values there is only .567 difference between them. Although there is statistical significance, it should not be inferred that the two groups are in vast disagreement on this question. That being the case, and with the relatively high mean values, it could be argued that airport managers and airport board members in the state of Indiana do perceive there would be a monetary savings for the airport if a board member were to complete training. Considering the fact that the airport managers are in the daily business of running the airport and, in most cases, have experience and an education relevant to airports, one could deduce that they are in a stronger position to answer this question. It should also be noted that both of the groups ranked this above a 2.5 , which is considered the fulcrum or dividing point between whether a respondent was agreeing or disagreeing with the statement.

\section{Research Question Two}

Is there a difference between airport managers and airport board members in regard to their level of agreement with the statement: "Airport board members would be more effective in their position if they completed training."

An analysis of variance was performed on the data collected on this question in order to determine if there were any statistically significant differences between the two samples collected for this study. The ANOVA results listed in Table 2 show that there is no statistically significant difference between the two groups of respondents $F(1,2)$ $=1.59, p<.05$.

Considering the results of the analysis of variance, it can be deduced that the airport managers and the airport board members are in agreement that airport board members would be more effective in their position if they completed training. Furthermore, in reviewing the combined mean ( $M$ $=4.42, S D=.712$ ) as a whole they not only agree but strongly agree with the statement.

\section{Research Question Three}

What topic areas for airport board member training do airport board members and airport managers consider most important to include in airport board member training? A Spearman Correlation indicated that a very strong relationship exists between the two groups when comparing the order in which the rank the importance of the topics. With that stated, using Table 3, which is a combined ranking of the means, becomes an appropriate way in which this question can be answered. Therefore, Table 3 lists the topics starting at the top with the most important to develop for 
training to the bottom which rank as least important to develop according to survey respondents.

\section{Research Question Four}

Is there a relationship between the airport managers and airport board members in their rankings of training topics? In order to determine what topics to include, a statistical method was utilized to determine if the two groups agreed on the ranking of the topic areas. Therefore, a Spearman Rank Order Correlation was performed.

The Spearman Correlation made it possible to use ordinal data to determine if, when ranked by means, there was a relationship or agreement between the two groups on the importance of the topic areas. A strong relationship was shown to exist between the two groups when considering how their respective means would rank order the topics. In other words, although the two groups did not have a perfect match on their respective rankings, the correlation of $\left(r_{s}=\right.$ $.9018)$ indicated a very strong positive relationship between the two groups.

The ordering of the means contained in Table 3 should serve not only as a justification to develop specific topics into training but should also be used as an order in which to develop them. Therefore, the null hypothesis for research question number four is rejected, and there is a very high degree of correlation shown to exist between how Indiana airport managers rank the topic areas and how Indiana airport board members rank them.

\section{CONCLUSIONS}

The data that was collected and statistically analyzed indicate that Indiana airport managers and airport board members perceive that training for airport board members would increase their job effectiveness and lead to some cost savings for the airport.

The results of this study could be useful in states where regulations and appointment of airport board members are similar to those serving in Indiana.

The study found that airport managers and airport board members both perceive a need for training.

There is much uniformity among all 60 respondents as to the importance of the training topics that were suggested as well as their level of importance.

There were topics suggested by the respondents, but many of the respondents commented that they felt the list was all-inclusive or did not suggest any additional training topics.

\section{RESULTS}

Table 1. ANOVA Results for Survey Question 23

\begin{tabular}{ccrrrrr}
\hline \multicolumn{2}{c}{ Question } & $\begin{array}{r}\text { Sum of } \\
\text { Squares }\end{array}$ & df & Mean Square & $F$ & Sig. \\
& & 4.817 & 1 & 4.817 & 5.965 & $*$ \\
\hline Monetary Savings & Between Groups & Wis \\
& Within Groups & 46.833 & 58 & .807 & & \\
& Total & 51.650 & 59 & & & \\
\hline
\end{tabular}

* = Significant at the .05 level

Table 2. ANOVA Results for Survey Question 24

\begin{tabular}{lrrrrrr}
\hline \multicolumn{2}{c}{ Question } & $\begin{array}{c}\text { Sum of } \\
\text { Squares }\end{array}$ & df & Mean Square & $F$ & Sig. \\
\hline $\begin{array}{c}\text { More Effective in } \\
\text { Position }\end{array}$ & Between Groups & .817 & 1 & .817 & 1.591 & .212 \\
& & & & & & \\
& & & & & & \\
& & & & & \\
& & & & & \\
& Within Groups & 29.767 & 58 & .513 & & \\
& Total & 30.583 & 59 & & \\
\hline
\end{tabular}


Table 3. Combined Airport Managers' and Airport Board Members' Topics Ranked According to Means in Descending Order

\begin{tabular}{clrr}
\hline Topic Areas & $\mathrm{n}$ & Mean & $\begin{array}{r}\text { Std. } \\
\text { Deviation }\end{array}$ \\
\hline Funding & 60 & 4.6167 & .61318 \\
Master Plan & 60 & 4.3000 & .88872 \\
Grant Assurances & 60 & 4.2833 & .86537 \\
Improve Image & 60 & 4.2833 & .82527 \\
Leg Air Board Member & 60 & 4.2500 & 1.01889 \\
Consultant Selection & 60 & 4.1667 & .90510 \\
Zoning & 60 & 4.0333 & .95610 \\
Gov Offices & 60 & 4.0167 & .91117 \\
Deal Media & 60 & 4.0000 & .86358 \\
Construction & 60 & 3.9833 & .91117 \\
Pub Relations & 60 & 3.9667 & .97366 \\
Interface Gov Bodies & 60 & 3.8667 & .87269 \\
Environment & 60 & 3.7500 & 1.01889 \\
Business Principals & 60 & 3.7167 & .97584 \\
Security & 60 & 3.6000 & 1.06086 \\
Self Inspection & 60 & 3.4833 & 1.06551 \\
Thru Fence & 60 & 3.4667 & 1.30795 \\
Hiring and Firing & 60 & 3.0167 & 1.34658 \\
Principles Flight & 60 & 2.9333 & 1.10264 \\
History & 60 & 2.9167 & 1.13931 \\
Noise & 60 & 2.7500 & 1.12935 \\
\hline
\end{tabular}

Table 4. Number of Response for Other Topics Suggested by Respondents

\begin{tabular}{cc}
\hline Training Topic & Responses \\
\hline Functions of an Airport Board & 4 \\
Roberts Rules of Order & 3 \\
Fuel Farm & 3 \\
Federal Aviation Regulations & 3 \\
Understanding the Value of an Airport & 3 \\
Airport Maintenance Procedures & 2 \\
How to Select Airport Board Members & 2 \\
What Makes an Airport Healthy & 1 \\
Airport Emergency Plans & 1 \\
\hline
\end{tabular}




\section{RECOMMENDATIONS}

In reviewing the findings of this study the following recommendations are given.

1. The data collected clearly indicates that the respondents believe that there is a need for additional airport board member training. An effective delivery method for training would be in the form of distance education via the internet. This asynchronous environment eliminates the problems inherent to workshops. Furthermore, an airport board member could revisit the material at their leisure.
2. In order to generalize to a larger population, this study should be replicated using the entire United States population of airport managers and airport board members.

3. Research should be conducted to determine the exact contents of training under each of the proposed topic areas.

4. The additional topic areas suggested by the survey respondents should be considered for possible inclusion in training.t

R. Troy Allen is an assistant professor in the aviation department at Indiana State University (I.S.U.) located in Terre Haute, IN. He holds a B.S. in Aviation Administration from ISU, a M.A.S. degree from Embry-Riddle Aeronautical University and a Ph.D. in Curriculum, Instruction and Media Technology from ISU. He was employed by the Indiana Department of Transportation, Aeronautics Section for eleven years where he served as the chief airport inspector and as a project manager. He holds a private pilot certificate, instrument rating, seaplane rating, advanced ground instructor certificate and is a certified member of AAAE. 


\section{REFERENCES}

Federal Aviation Administration. (2006, October). National Plan of Integrated Airport System. Retrieved May 20, 2007, from Federal Aviation Administration Reports Online via FAA Access:

http://www.faa.gov/airports_airtraffic/airports/planning_capacity/npias/reports/media/2007/npias_2007_narrative.pdf

Fraenkel, J. R. \& Wallen., N. E. (2006). How to design and evaluate research in education. New York: McGraw-Hill.

Peters, R.W. (2005). The need for a master of science program in automotive technology management as perceived by automotive professionals. Dissertation Abstracts International 66 (12), 4288.

Quilty, S. M. (2003). Achieving recognition as a world class airport through education and training. Journal of Air Transportation, 8(1), 4-13.

Research Randomizer. Retrieved June, 9, from 2006http://www.randomizer.org/form.htm

Salant, P. \&. Dillman, D.A. (1994). How to conduct your own survey. New York: John Wiley and Sons, Inc.

Schaffer, M. D. (2002). The need for emphasis on teaching the content of certain subject areas and teaching concepts related to certain packaging industry job titles as perceived by packaging professional in Indiana and the surrounding states. Dissertation Abstracts International 62(10), 4758. 


\section{APPENDIX A}

\section{Survey Questionnaire}

\section{Respondent's Name:}

Telephone Number:

Title:

Hello, Mr. /Ms. this is Troy Allen. I am currently an Assistant Professor in the Aerospace Department at Indiana State University. As a part of my doctoral dissertation, I am conducting a survey of 30 Indiana airport managers and 30 Indiana airport board members. The intent of this survey is to determine if there would be value in offering additional airport board member training. Additionally, I am researching what the content would be of such training. This short telephone survey will only require a few minutes of your time to complete. All of the data collected for this survey will be kept confidential and secured in a locked file cabinet. Are you willing to participate?

The following 21 topic areas are possible subject matter if training were developed for airport board members. I will state a possible topic area and then give you a moment to consider if you believe it would be important to include this area in airport board member training. Please state your level of agreement by selecting a one through five with a one indicating "not important" and a five indicating you believe it would be "extremely important". You do not have to answer any of the questions found in this survey that you do not feel comfortable with.

\section{Not Important Extremely Important}

1. Airport Security

2. Airport Construction Activity

3. Airport Funding Mechanisms

4. Airport Master Plan

5. Airport Noise

6. Thru the fence operations

7. Airport Self Inspections

8. Hiring and Firing Employees

9. Aviation History

10. Business Principles

11. Environmental Issues

12. Federal and State Government Aviation Offices

13. Land Control Measures and Uses/Zoning

14. Legislation Pertaining to Airport Board Members

15. Interfacing with other Government Bodies

16. Principles of Flight

17. Public Relations

18. Selection of Consultants

19. Effectively Dealing with the Media

20. Airport Obligations/Grant Assurances/Compliance

$\begin{array}{lllll}1 & 2 & 3 & 4 & 5 \\ 1 & 2 & 3 & 4 & 5 \\ 1 & 2 & 3 & 4 & 5 \\ 1 & 2 & 3 & 4 & 5 \\ 1 & 2 & 3 & 4 & 5 \\ 1 & 2 & 3 & 4 & 5 \\ 1 & 2 & 3 & 4 & 5 \\ 1 & 2 & 3 & 4 & 5 \\ 1 & 2 & 3 & 4 & 5 \\ 1 & 2 & 3 & 4 & 5 \\ 1 & 2 & 3 & 4 & 5 \\ 1 & 2 & 3 & 4 & 5 \\ 1 & 2 & 3 & 4 & 5 \\ 1 & 2 & 3 & 4 & 5 \\ 1 & 2 & 3 & 4 & 5 \\ 1 & 2 & 3 & 4 & 5 \\ 1 & 2 & 3 & 4 & 5 \\ 1 & 2 & 3 & 4 & 5 \\ 1 & 2 & 3 & 4 & 5 \\ 1 & 2 & 3 & 4 & 5\end{array}$

21. Improving Public Image

Not Important

Extremely Important

22. Other Topic

$\begin{array}{lllll}1 & 2 & 3 & 4 & 5\end{array}$




\section{Perceived Need for Training}

For the last two statements, please indicate your level of agreement with each statement on a scale of $1-5$, with a response of 1 indicating strongly disagree and a response of 5 indicating strongly agree.

23. I perceive their would be a monetary savings for the airport if an airport board member were to receive training.

$$
\text { Strongly Disagree Strongly Agree }
$$

$\begin{array}{lllll}1 & 2 & 3 & 4 & 5\end{array}$

24. An airport board member would be more effective in their position if they completed training.

\section{Strongly Disagree Strongly Agree}

$\begin{array}{lllll}1 & 2 & 3 & 4 & 5\end{array}$ 